\title{
ANALISA AKURASI PENYALURAN DANA PENGEMBALIAN TABUNGAN KEPADA PNS MELALUI BANK BRI (PERSERO), TBK DENGAN MENGGUNAKAN METODE ANALISA SWOT
}

\author{
Gatut D Purwoko ${ }^{1)}$ \\ 1) dosen universitas pamulang, email : gatutdp@yahoo.com
}

\section{ARTICLES \\ INFORMATION \\ JURNAL SEKURITAS \\ (Saham, Ekonomi, Keuangan dan Investasi ) \\ Vol.2, No. 1, September 2018 \\ Halaman : $119-137$ \\ C L LPPM \& Prodi Manajemen \\ UNVERSITAS PAMULANG \\ ISSN (online) : 2581-2777 \\ ISSN (print) : :2581-2696}

Keyword :

Analisa Akurasi Penyaluran

Dana, Analisa SWOT

JEL. classification :

D79, E32, G30, M20

\section{Contact Author :}

PRODI MANAJEMEN UNPAM

JL.Surya Kencana No.1 Pamulang

Tangerang Selatan - Banten

Telp. (021) 7412566, Fax (021) 7412491 Email :

jurnalfinance.unpam@gmail.com
Penelitian ini bertujuan untuk mengetahui 1) apakah Penyaluran dana Pengembalian Tabungan Perumahan melalui Bank BRI (Persero), Tbk sudah berjalan dengan baik sesuai prinsip keterbukaan, akuntabilitas, dapat dipercaya, bertanggungjawab dan adil serta pemantauan manajemen terhadap visi dan misi

Penelitian ini menggunakan metode penelitian kuantitatif dan kualitatif dengan menggunakan Jumlah populasi sebanyak 34 cabang Bank BRI di seluruh Indonesia. Teknik penentuan sampel penelitian ini menggunakan data cabang yang paling tinggi melakukan kesalahan bayar dan metode yang digunakan untuk peneilitian ini adalah dengan menggunakan Metode Anasilisis SWOT.

Berdasarkan hasil analisa SWOT yang telah dilakukan bahwa peta terdapat di Kuadran ke II, yang artinya ada 2 faktor yang sangat dominan, yaitu faktor Kekuatan dan faktor Ancaman, yang berarti bahwa Faktor Kekuatan yang cukup besar dalam mengatasi faktor Ancaman yang timbul dari luar.

This study aims to know 1) whether the Distribution of Housing Savings Returns through Bank BRI (Persero) Tbk has been running well according to the principles of openness, accountability, credibility, responsibility and fair and monitoring the management of existing vision and mission.

This research uses quantitative and qualitative research methods by using the total population of 34 branches of Bank BRI throughout Indonesia. The technique of determining the sample of this study using the data of the highest branch to make a mistake pay and methods used for this research is to use SWOT Analysis Method.

Based on the results of SWOT analysis that has been done that the map is in Quadrant to II, which means there are two factors that are very dominant, namely the Power factor and Threat factor, which means that a considerable strength factor in overcoming the threats that arise from outside. 


\section{A. Pendahuluan}

Badan Pertimbangan Tabungan Perumahan Pegawai Negeri Sipil (BAPERTARUM-PNS) dibentuk berdasarkan Keputusan Presiden RI Nomor 14 tahun 1993 tentang Tabungan Perumahan Pegawai Negeri Sipil Jo Keputusan Presiden RI Nomor 46 tahun 1994 tentang Perubahan Atas Keputusan Presiden Nomor 14 tahun 1993 dengan tujuan untuk mengelola tabungan perumahan PNS. Terbentuknya badan ini diharapkan dapat meningkatkan kesehjateraan PNS, Khususnya di bidang perumahan melalui Bantuan Uang Muka KPR dan Bantuan Sebagian Biaya Membangun Rumah di atas tanah sendiri bagi yang belum memiliki rumah dan Pengembalian Tabungan yang diberikan kepada PNS pada saat berhenti bekerja baik karena pensiun, meninggal dunia atau berhenti bekerja karena sebab lain yang selama dinas aktifnya belum pernah memanfatkan bantuan dari BAPERTARUM-PNS.

Berdasarkan Keputusan Presiden No.14 Tahun 1993 tentang Tabungan Perumahan Pegawai Negeri Sipil, yang dimaksud dengan Tabungan Perumahan Pegawai Negeri Sipil adalah "Iuran yang dipotong dari setiap PNS berdasarkan azas keadilan dan kegotongroyongan yang peruntukkannya digunakan untuk penyediaan uang muka pembelian rumah melalui kredit pemilikan rumah dari perbankan".

Sedangkan konsep Tabungan Perumahan Rakyat menurut Kementerian Negara Perumahan Rakyat adalah untuk mendorong masyarakat menabung agar beban cicilan KPR dapat lebih terjangkau bagi Masyarakat Berpenghasilan Rendah, dan awal program ini diprioritaskan memfasilitasi Program KPRS/KPRS Mikro Bersubsidi, dengan cara Pemerintah (Pusat dan Daerah) akan memberikan fasilitas subsidi perumahan. Subsidi tersebut akan dimanfaatkan bagi masyarakat sebagai insentif untuk menabung sekaligus untuk memperkuat likuiditas BPR dalam penerbitan pokok pinjaman untuk KPRS/KPRS Mikro".

Program tabungan semacam ini telah diterapkan di beberapa negara, seperti China, Brazil, Meksiko, dan Singapura. Di Singapura, misalnya, program ini disebut Central Providen Fund (CPF) yang semula ditujukan untuk membiayai perumahan seluruh karyawan yang bekerja di negara pulau itu, baik swasta maupun pegawai negeri. Setelah sukses, CPF tidak hanya membiayai kepemilikan rumah, tetapi lebih luas lagi seperti biaya renovasi, penggantian rumah, kesehatan serta investasi bagi profesional yang ingin berusaha. Dalam program ini dana dihimpun melalui pemotongan gaji karyawan sebesar $21 \%$ ditambah bantuan (keharusan) dari perusahaan atau instansi tempatnya bekerja sebesar $19 \%$ dari gaji.

Program Pengembalian Tabungan atau selanjutnya disingkat "PT", adalah Jumlah Tabungan Perumahan PNS yang diberikan kepada PNS pada saat berhenti bekerja baik karena pensiun, meninggal dunia atau berhenti bekerja karena sebab lain dan selama dinas aktifnya belum pernah memanfatkan bantuan dari BAPERTARUM-PNS.

Adapun jumlah besaran iuran tabungan perumahan yang dipotong dari setiap PNS adalah berdasarkan golongan ruang masing-masing PNS, yaitu sebesar :
- Golongan I
:Rp. 3.000,-
- Golongan II
: Rp. 5.000,-
- Golongan III
:Rp. 7.000,-
- Golongan IV
: Rp.10.000,-

Dasar Pelaksanaan penyaluran pembayaran "PT" ini adalah berdasarkan :

1. Keputusan Presiden No.14 Tahun 1993 tentang Tabungan Perumahan Pegawai Negeri Sipil.

2. Keputusan Presiden No.46 Tahun 1994 tentang Perubahan Atas Keputusan Presiden No.14 Tahun 1993 tentang Tabungan Perumahan Pegawai Negeri Sipil. 
Pada awalnya program "PT" ini diberikan kepada PNS melalui PT.TASPEN bersamaan ketika PNS mengambil pensiunnya di PT.TASPEN. Namun karena adanya beberapa perubahan kebijakan yang terjadi di PT TASPEN, maka sejak tahun 2003 pengurusan pengambilan "PT" dialihkan ke PT Bank Rakyat Indonesia.

Pemilihan PT Bank Rakyat Indonesia sebagai Bank Pembayar untuk Pengembalian Tabungan karena PT Bank Rakyat Indonesia memiliki cabang yang menjangkau PNS sampai ke pelosok daerah dimana PNS bekerja dan, penggunaan jaringan "Sistem Host To Host" yang dimiliki PT Bank Rakyat Indonesia sangat membantu PNS dalam memperoleh Pengembalian Tabungannya.

Semula pelaksanaan kerjasama ini sangat membantu BAPERTARUM-PNS dalam melayani PNS di seluruh Indonesia. Namun dalam perjalanannya mulai timbul permasalahan dalam pelaksanaan pembayaran "PT" tersebut, yaitu seringnya "Kesalahan Bayar" yang dilakukan oleh petugas pelaksana PT Bank Rakyat Indonesia kepada PNS di lapangan, yang tentunya hal ini sangat merugikan bagi BAPERTARUM-PNS khususnya PNS dalam menerima kembali Tabungan Perumahannya. Jumlah Kesalahan Bayar terhadap pembayaran Pengembalian Tabungan dapat terlihat dari Tabel dibawah ini :

Tabel 1 : Transaksi PT dan Kesalahan Bayar

\begin{tabular}{|c|c|c|c|c|c|c|}
\hline \multirow{2}{*}{ NO } & \multirow{2}{*}{ TAHUN } & \multicolumn{2}{|c|}{ TRANSAKSI PT } & \multicolumn{2}{|c|}{$\begin{array}{c}\text { KESALAHAN } \\
\text { BAYAR }\end{array}$} & \multirow[t]{2}{*}{$\%$} \\
\hline & & Rp. & PNS & Rp. & PNS & \\
\hline 1 & 2005 & 62.400 & 59.808 & 540 & 7.873 & $0,87 \%$ \\
\hline 2 & 2006 & 66.700 & 58.649 & 701 & 11.855 & $1,05 \%$ \\
\hline 3 & 2007 & 71.310 & 57.302 & 149 & 1.990 & $0,21 \%$ \\
\hline 4 & 2008 & 66.864 & 87,15 & 1.143 & 14.291 & $1,71 \%$ \\
\hline 5 & 2009 & 101.290 & 72.871 & 1.837 & 14.200 & $1,81 \%$ \\
\hline 6 & 2010 & 99.717 & 73.286 & 1.647 & 12.576 & $1,65 \%$ \\
\hline
\end{tabular}

Sumber data : BAPERTARUM-PNS (2010)

Dari tabel diatas terlihat bahwa total jumlah kesalahan bayar tahun 2005 sebesar Rp.540 juta atau sebesar 0,87\% dari total transaksi "PT" sebesar Rp.62,4 Milyar meningkat terus sampai dengan tahun 2009 pada titik tertinggi sebesar Rp.1,837 Milyar atau sebesar 1,87\% dari total transaksi "PT" sebesar Rp.101.249 Milyar. Penurunan terjadi pada tahun 2007 sebesar Rp.149 juta dan tahun 2010 sebesar Rp.1,647 Milyar. Namun hal ini bukan berarti adanya perbaikan pelayanan dalam penyaluran pembayaran "PT". Karena jumlah tingkat kesalahan bayar timbul masih sangat besar dan signifikan sekali sehingga harus segera dilakukan "perubahan" untuk meminimalisir tingginya tingkat kesalahan bayar tersebut.

Tingginya tingkat Kesalahan Bayar ini tentunya sangat berpengaruh terhadap citra BAPERTARUM-PNS khususnya dalam memberikan pelayanan yang optimal terhadap PNS baik secara materiil maupun immaterial.

\section{B. Identifikasi Masalah}

Berdasarkan uraian Latar Belakang permasalahan tersebut di atas, masalah yang muncul dalam pembayaran "PT" dari BAPERTARUM-PNS ke PT Bank Rakyat Indonesia dapat diidentifikasikan sebagai berikut :

1. Tingginya Tingkat Kesalahan Bayar yang dilakukan oleh PT BRI (Persero), Tbk kepada PNS 
2. Tidak Lengkapnya Data Riwayat Kepangkatan PNS yang diberikan kepada petugas PT BRI di lapangan, yang dapat mengakibatkan jumlah yang dibayarkan tidak sesuai dengan Tabungan yang harus di terima PNS.

3. Lamanya Proses Pengambilan PT di cabang PT BRI yang dikarenakan masalah Komputer yang Offline atau masalah administrasi lainnya (tidak kelengkapan.

4. Tidak terdaftarnya NIP PNS pada database BAPERTARUM-PNS, dikarenakan belum lengkapnya Sistim Database PNS yang dimiliki saat ini, sehingga mengakibatkan proses pengembalian PT belum dapat diproses saat itu.

\section{Perumusan Masalah}

Berdasarkan identifikasi masalah seperti yang diuraikan diatas, maka penulis memilih masalah yang akan diteliti di dalam tesis ini, yaitu tentang masalah Tingginya Tingkat Kesalahan Bayar dalam pelaksanaan pembayaran PT melalui PT Bank Rakyat Indonesia serta bagaimana cara untuk "meminimalisasi" tingkat kesalahan bayar tersebut.

\section{Pembatasan Masalah}

Penelitian ini dibatasi pada permasalahan-permasalahan sebagai berikut :

1. Lokasi yang diteliti terbatas pada cabang atau regional yang paling banyak tingkat kesalahan bayarnya, yaitu : Propinsi Sumatera Barat dan Propinsi Sumatera Selatan melalui program Bimbingan Teknis pada periode bulan Juni 2009 s/d bulan Juni 2010.

2. Data yang akan diteliti adalah Transaksi pembayaran "PT" tahun 2005 sampai dengan tahun 2010.

3. Penelitian ini hanya meliputi penyaluran Pengembalian Tabungan saja dan tidak mencakup pada laporan Keuangan BAPERTARUM-PNS pada periode tersebut. Hal ini dimaksudkan bahwa fokus utama pembahasan tesis ini hanya pada program Pengembalian Tabungan kepada PNS. Karena bila membahas Laporan Keuangan BAPERTARUM-PNS, maka harus membahas program layanan BAPERTARUM-PNS yang ada seperti Bantuan Uang Muka atau Bantuan Sebagian Biaya Membangun diatas lahan milik PNS sendiri atau permasalahan lain yang timbul dalam Laporan Keuangan tersebut.

\section{F. Tujuan Penelitian}

Adapun tujuan dari penelitian ini adalah untuk "meminimalisasi" tingginya tingkat Kesalahan Bayar "PT" di PT Bank Rakyat Indonesia.

\section{G. Manfaat Penelitian}

1. Manfaat praktis, penelitian ini dapat memberikan masukan kepada BAPERTARUMPNS untuk mengambil Kebijakan yang Strategis terhadap pelaksanaan Pembayaran "PT" melalui PT Bank Rakyat Indonesia.

2. Manfaat Bagi Peneliti lain, Sebagai referensi dalam penelitian- penelitian lebih lanjut khususnya mengenai masalah yang sama.

3. Manfaat Bagi peneliti, menambah wawasan peneliti tentang pelaksanaan penyaluran dana TAPERUM-PNS khususnya Pengembalian Tabungan dan pengaruhnya terhadap kepuasan pelayanan kepada PNS di seluruh Indonesia.

\section{H. Tinjauan Theoritis}

1. Pengertian Tabungan Perumahan

Berdasarkan Keputusan Presiden No.14 tahun 1993 adalah luran yang wajib disetor oleh setiap PNS dalam suatu Tabungan Perumahan PNS yang pemanfaatannya khusus digunakan untuk penyediaan uang muka bagi PNS yang semasa aktifnya akan membeli rumah secara kredit melalui Lembaga Perbankan, berdasarkan azas 
keadilan dan gotong royong diantara Pegawai Negeri Sipil. Sedangkan bagi PNS yang pada masa aktifnya belum memanfaatkan tabungan Perumahan ini, maka akan dikembalikan pada saat pensiun, meninggal dunia atau sebab-sebab lain.

Program Tabungan Perumahan ini erat kaitannya dengan program pemerintah khususnya dalam bidang perumahan. Salah satu program pembangunan perumahan yang digulirkan di negeri ini adalah pengadaan rumah bagi Pegawai Negeri Sipil (PNS). Mengapa PNS? Dalam kesehariannya, PNS memiliki tugas yang teramat vital. Mereka motor penggerak pembangunan dari masa ke masa. Setiap warga negara, mau-tak-mau, suka-tak-suka, akan selalu berhubungan dengan aparatur birokrasi itu, dari mereka lahir hingga meninggal dunia.

Jika ditarik ke belakang, kebijakan untuk memenuhi kebutuhan perumahan bagi aparatur birokrasi telah berlangsung sejak jaman kolonial Belanda. Melalui Burngerlyke Woning Regeling (BWR) staatblad 1934 No. 147 berikut aturan-aturan perubahannya, pemerintah Belanda mengatur pengadaan tempat tinggal untuk PNS dengan sistem sewa.

Kala itu, pemerintah membangun rumah-rumah dinas untuk pegawai dan rumah jabatan untuk pejabat pemerintah dengan anggaran pemerintah sendiri. Namun, pada masa pendudukan Jepang, kegiatan ini terhenti karena situasi perang.

Setelah penyerahan kedaulatan, program ini kembali dilanjutkan. Pemerintah membangun kawasan perumahan di berbagai kota yang kemudian dimanfaatkan PNS dari berbagai instansi pemerintah dengan sistem sewa. Di Yogyakarta, misalnya, dibangun Komplek Perumahan Baciro, sedangkan di Jakarta ada Komplek Perumahan Panaragan Baru. Memasuki era 1970-an, pemerintah mengeluarkan kebijakan baru yang mengijinkan PNS dengan syarat-syarat tertentu untuk membeli rumah dinas yang mereka tempati. Uang hasil penjualan rumah tersebut akan digunakan untuk membangun rumah dinas baru bagi PNS yang lain.

Namun, memasuki era 1980-an, pola sewa-beli itu dirasa sudah tak mungkin lagi dilakukan. Jumlah PNS bertambah menjadi begitu besar sejalan dengan pertumbuhan laju pembangunan nasional. Bersamaan dengan itu anggaran pemerintah semakin terbatas, sehingga upaya untuk mengadakan fasilitas perumahan bagi PNS tidak lagi memungkinkan. Keadaan ini semakin memperberat anggaran pemerintah ketika terjadi kelesuan perekonomian nasional akibat anjloknya harga minyak pada awal tahun 1980-an. Akhirnya pada tahun 1984, pemerintah mengambil keputusan yang sangat berat, meniadakan dana pembangunan perumahan dinas bagi PNS.

Sebagai gantinya pemerintah memberikan kesempatan bagi PNS untuk membeli rumah melalui fasilitas Kredit Pemilikan Rumah (KPR) dari Bank Tabungan Negara (BTN). PNS pun mendapat hak isitimewa berupa KPR bersubsidi yang memungkinkan mereka mencicil rumah yang dibelinya dengan suku bunga di bawah KPR komersial.

Kendati didukung dengan beragam kemudahan, bukan berarti jalan PNS untuk mendapatkan rumah semakin lapang. Persoalan baru pun muncul dan terasa begitu memberatkan, yaitu uang muka pembelian rumah yang jumlahnya bisa mencapai 20 30 persen dari harga jual rumah. PNS pun kewalahan menyediakannya. Padahal, kalau tidak mampu menyediakannya, fasilitas KPR-BTN tidak akan mengucur.

Pemerintah pun segera mencari jalan keluar dengan strategi yang tepat. Berangkat dari azas kegotong-royongan, pemerintah mempelajari potensi yang dimiliki PNS untuk menolong dirinya sendiri secara bersama-sama, dengan semangat gotong royong. Dengan falsafah bangsa yang sudah berakar ini, banyak beban berat dapat diatasi karena dipikul bersama-sama. 
Setelah melakukan pengkajian secara seksama, pemerintah pun berkesimpulan bahwa masalah uang muka yang melilit PNS dapat dipecahkan jika PNS dilibatkan dalam suatu program tabungan perumahan.

Berdasarkan kajian-kajian yang dilakukan ditambah dengan masukan dari berbagai instansi terkait yang disepakati dalam sidang Badan Kebijaksanaan Perumahan Nasional (BKPN), akhirnya Menteri Negara Perumahan Rakyat mengajukan usulan Program Tabungan Perumahan Pegawai Negeri Sipil (TaperumPNS) kepada Presiden Soeharto. Usulan ini menjadi konkret dengan diterbitkannya Keputusan Presiden No. 14 tahun 1993 tentang Tabungan Perumahan Pegawai Negeri Sipil, tertanggal 15 Pebruari 1993. Sebagai pengelola tabungan tersebut dibentuk Badan Pertimbangan Tabungan Perumahan Pegawai Negeri Sipil (BAPERTARUM-PNS) dengan Ketua langsung dijabat oleh Presiden dan Menteri Negara Perumahan Rakyat sebagai Ketua Harian.

Dalam menjalankan fungsinya, Bapertarum-PNS lebih ditekankan pada aspek penghimpunan dana, sedangkan pembangunan rumahnya diserahkan kepada pihakpihak yang layak, seperti Perum Perumnas dan pengembang yang memenuhi kualifikasi. Penghimpunannya pun dipilih dengan cara langsung memotong gaji sebelum diterima PNS. Setiap PNS menabung sesuai dengan golongan pangkatnya. Golongan I Rp. 3000, Golongan II Rp 5000, Golongan III Rp 7000, dan Golongan IV Rp 10.000. Hasilnya, sebesar $40 \%$ disimpan untuk pemupukan dana dan $60 \%$ sisanya digunakan untuk bantuan uang muka kredit kepemilikan rumah (KPR) atau sebagian biaya membangun rumah di atas tanah sendiri. Besarnya bantuan bervariasi berdasarkan golongan PNS penerimanya. Untuk PNS golongan I, besarnya bantuan ditetapkan sebanyak Rp 1,2 juta, Rp 1,5 juta untuk golongan II, Rp 1,8 juta untuk golongan III, sementara PNS golongan IV mendapatkan bantuan sebesar Rp 2,1 juta. Adapun PNS yang tidak memanfaatkan layanan BapertarumPNS akan menerima kembali dana tabungannya sebesar pokok tabungan pada saat berhenti bekerja karena pensiun, meninggal dunia, atau karena sebab-sebab lain.

Untuk memahami lebih jauh lagi tentang Tabungan Perumahan, dibawah ini diberikan beberapa definisi tentang tabungan Perumahan yang dapat memberikan gambaran mengenai konsep-konsep dasar yang terkandung dalam Tabungan Perumahan, yaitu dari :

1) Artle, Roland and Pravin Varaiya (1978). Life Cycle Consumption and Homeownership, Journal of Economic Theory, 18, 1, 38-58: "Housing Provident Fund (HPF) adalah merupakan salah satu alat yang dikembangkan oleh pemerintah Cina dalam upaya untuk memprivatisasi perumahan yang sebelumnya dimiliki publik. Program ini telah berhasil selama beberapa dekade terakhir dalam membantu privatisasi saham perumahan perkotaan di Cina. Tantangan untuk HPF adalah untuk memotivasi orang peserta yang berada dalam sistem tetapi belum membeli rumah mereka. Dengan Program Housing Privident Fund, Pemerintah China telah memulai pada upaya untuk mengurangi jumlah penyewa yang tinggal di perumahan milik umum.

Dana tabungan perumahan ini awalnya diperkenalkan sebagai program percontohan di Shanghai pada akhir 1991, dan diperpanjang secara nasional pada tahun 1995. Program ini terbuka untuk karyawan instansi pemerintah, BUMN, perguruan tinggi, rumah sakit, dan beberapa perusahaan semi-negara. Baru-baru ini pemerintah telah mengamanatkan bahwa semua karyawan yang memenuhi syarat harus mengikuti program ini, meskipun pekerja swasta bekerja tidak harus untuk berpartisipasi.

Seorang karyawan yang bergabung dengan program ini setuju untuk memiliki antara $4 \%$ dan $10 \%$ dari gaji mereka disimpan ke dalam sebuah rekening khusus 
di bank milik negara. Sementara account ini hanya membayar tingkat bunga bebas risiko, majikan peserta memberikan cocok dengan satu-untuk-satu untuk setiap Yuan yang deposito karyawan ke account. Dana ini disimpan ke dalam account yang sama dan mereka juga mendapatkan tingkat risiko-bebas. Karyawan memiliki rekening, dan semua uang di dalamnya, meskipun mereka hanya dapat menggunakan dana untuk pembelian rumah. Haruskah karyawan mati, dana mereka menjadi bagian dari harta mereka. Setelah di program, namun, karyawan harus terus iuran bulanan mereka ke rekening HPF mereka sampai mereka pensiun, meninggal dunia, atau dipisahkan dari majikan mereka. Karyawan mungkin tidak secara sukarela mengundurkan diri dari program ini sementara mereka masih dipekerjakan oleh badan negara atau disponsori negara. Kecuali untuk tidak bisa menarik diri dari program ini, ini komponen tabungan dari sistem sangat mirip dengan 401 (k) atau program pensiun IRA di Amerika Serikat.

2) Di Singapura, badan yang mengelola perumahan bagi para anggotanya yang disebut "Central Providen Fund (CPF)". Pada mulanya skema CPF sebagian besar dikhususkan untuk tabungan pensiun saja. Kontribusi statis dari masingmasing anggotanya adalah sebesar $5 \%$ baik oleh pemberi kerja dan karyawan pada gaji dan individu yang disimpan dalam suatu CPF account dan pada akhirnya dapat diambil oleh yang bersangkutan pada saat pensiun sesuai yang dilakukan oleh BAPERTARUM-PNS.

3) Ohio Housing Finance Agency adalah sebuah lembaga indenpenden yang dibentuk dan didirikan paa tahun 2005 berdasarkan amandemen pada pasal 431 mengenai pembiayaan perumahan. Lembaga tersebut menyediakan kredit murah kepada pemilik rumah dan KPR untuk pembeli rumah, penawaran insentif keuangan bagi pengembang penyediaan rumah untuk meningkatkan penyediaan perumahan sewa yang terjangkau dan membantu pengembang properti untuk memperhatikan keamanan, lingkungan yang baik bagi perumahan murah.

4) Kementerian Negara Perumahan Rakyat :"Konsep TPR (Tabungan Perumahan Rakyat) adalah untuk mendorong masyarakat menabung agar beban cicilan KPR dapat lebih terjangkau bagi Masyarakat Berpenghasilan Rendah, dan awal program ini diprioritaskan memfasilitasi Program KPRS/KPRS Mikro Bersubsidi, dengan cara Pemerintah (Pusat dan Daerah) akan memberikan fasilitas subsidi perumahan. Subsidi tersebut akan dimanfaatkan bagi masyarakat sebagai insentif untuk menabung sekaligus untuk memperkuat likuiditas BPR dalam penerbitan pokok pinjaman untuk KPRS/KPRS Mikro".

\section{Dasar Hukum}

a. Keputusan Presiden No.14 Tahun 1993 tentang Tabungan Perumahan Pegawai Negeri Sipil.

b. Keputusan Presiden No.46 Tahun 1994 tentang Perubahan Atas Keputusan Presiden No.14 Tahun 1993 tentang Tabungan Perumahan Pegawai Negeri Sipil.

c. Keputusan Kepala Pelaksana Sekretariat Tetap BAPERTARUM-PNS Nomor: 90/KPTS/TAPERUM-PNS/VI/2000 tentang Petunjuk Teknis Penyaluran Bantuan BAPERTARUM-PNS.

d. Perjanjian Kerjasama antara BAPERTARUM-PNS dengan PT Bank Rakyat Indonesia No. 20/Add.PKS/TAPERUM-PNS/9/2008 \& B.547-DIR/HBL/09/08 tanggal 1 September 2008 tentang Pengembalian Tabungan Perumahan Pegawai Negeri Sipil.

\section{Mekanisme pelaksanaan kerjasama penyaluran "PT"}


Langkah-langkah yang harus dipenuhi dalam pelaksanaan kerjasama Penyaluran

Pembayaran "PT" dengan PT Bank Rakyat Indonesia, adalalah terdiri dari :

a. Penandatanganan Kerjasama Pelayanan Penyaluran Pengembalian Tabungan antara BAPERTARUM-PNS dengan PT Bank Rakyat Indonesia, sebagai landasan hukum dalam pelaksanaan layanan Pengembalian Tabungan.

b. Penyusunan Standar Operasional dan Prosedur Penyaluran Pembayaran Pengembalian Tabungan, sebagai Landasan Hukum dalam pelaksanaan operasional pelayanan Pengembalian Tabungan kepada PNS melalui PT Bank Rakyat Indonesia.

c. Memberikan Sosialisasi tentang mekanisme penyaluran Pengembalian Tabungan beserta permasalahannya, sebagai tindaklanjut dari pelaksanaan Perjanjian Kerjasama yang telah ditandatangani bersama.

d. PT Bank Rakyat Indonesia berkewajiban mengirimkan Pelaporan Realisasi Pencairan Pengembalian Tabungan sebagai dasar BAPERTARUM-PNS melakukan pengawasan terhadap pelaksanaan Pencairan Pengembalian Tabungan melalui PT Bank Rakyat Indonesia.

e. Pengawasan baik secara "On Desk" maupun tinjauan langsung ke lapangan khususnya cabang-cabang PT Bank Rakyat Indonesia untuk mengetahui permasalahan yang timbul di lapangan.

f. Monitoring dan evaluasi terhadap hasil pengawasan sebagai tindak lanjut terhadap permasalahan yang timbul di lapangan.

\section{Perhitungan Pembayaran "PT"}

Konsep perhitungan pembayaran "PT" adalah dihitung berdasarkan luran yang dipotong sejak PNS tersebut diangkat dan bekerja sampai dengan masa PNS tersebut pensiun sesuai dengan golongan ruang yang dimiliki oleh PNS tersebut. Sebagai contoh adalah : Bapak Budi adalah PNS di Dep. Dalam Negeri Jakarta, dan diangkat menjadi PNS pada tanggal 01-01-1977 pada usia 24 Tahun digolongan II/a pada tanggal 01-06-2009 yang bersangkutan memasuki usia pensiun dengan masa kerja selama 32 tahun, dengan riwayat kepangkatan/golongan bapak Budi sebagai berikut:
1. TMT : 01-01-1977 diangkat sebagai PNS Gol II/a
2. TMT : 01-04-1993 naik menjadi
3. TMT :01-04-2009 naik menjadi
Gol III/a
4. TMT : 01-06-2009 Pensiun
Gol IV/a

Perlu diiformasikan bahwa Perhitungan Pengembalian Tabungan Dihitung mulai Tanggal 1 Januari 1993, maka Perincian Pengembalian Tabungan Bapak Budi adalah sebagai berikut:
1. 01-01-1993 s/d 31-03-1993 Gol II $15.000,-$
2. 01-04-1993 s/d 31-03-2009 Gol III 1.337.000,-
3. $01-04-2009 \mathrm{~s} / \mathrm{d}$ 01-06-2009 Gol IV= 20.000,-
Jumlah Tabungan
$=3$ bulan $\times$ Rp.5.000,- $=$ Rp.
$=191$ bulan $\times$ Rp7.000,- $=R p$.
$=\quad 2$ Bulan $x$ Rp.10.000,- $=$ Rp.

$$
=\text { Rp. 1.372.000,- }
$$

\section{Persyaratan PNS Yang Berhak Mendapatkan "PT"}

Persyaratan PNS penerima PT adalah semua Pegawai Negeri Sipil yang :

a. Mengiur Tabungan Perumahan. 
b. Bukan berasal dari lingkungan POLRI, Militer, BUMN, BUMD, Perhutani, Berhenti sebagai Pegawai Negeri Sipil, baik karena memasuki usia Pensiun atau meninggal dunia atau karena sebab lainnya.

c. Semasa masih aktif belum memanfaatkan atau tidak menerima layanan Taperum baik berupa Bantuan Uang Muka (UM-KPR) atau Bantuan Sebagian Biaya Membangun Rumah (BM) kecuali program layanan Pinjaman.

\section{Kerangka Berfikir}

Adapun Kerangka Berpikir dari Penyaluran Dana Taperum ini adalah merupakan alur permohonan pencairan PT sejak awal proses permohonan dari PNS sampai dengan proses pembayaran dana PT dapat dicairkan oleh PNS tersebut, yaitu :

1. PNS datang ke Instansi setempat untuk mengambil Formulir Pengembalian TAPERUM-PNS yang telah ditanda-tangani/disyahkan oleh Pejabat yang berwewang dari Instansi yang bersangkutan.

2. PNS datang ke Kantor Cabang PT Bank Rakyat Indonesia pembayar dengan membawa formulir dan dokumen pendukung berupa SK Golongan, Kartu Pegawai dan SK Pensiun.

- Kantor Cabang PT Bank Rakyat Indonesia melakukan Pengecekan terhadap keabsahan Formulir Pengembalian TAPERUM-PNS dan bila sesuai dengan persyaratan maka akan membayarkan dana PT kepada PNS yang bersangkutan.

- Apabila belum/tidak dapat dibayarkan, Kantor cabang PT Bank Rakyat Indonesia Pembayar akan mengembalikan seluruh dokumen kepada PNS dan menyarankan untuk menghubungi BAPERTARUM untuk mendapatkan penyelesaian lebih lanjut.

- PNS yang belum dapat dibayarkan, menghubungi/menyurati BAPERTARUM.

- Berdasarkan laporan/surat dari PNS, BAPERTARUM melakukan penelitian dan verifikasi serta menjawab permasalahan PNS.

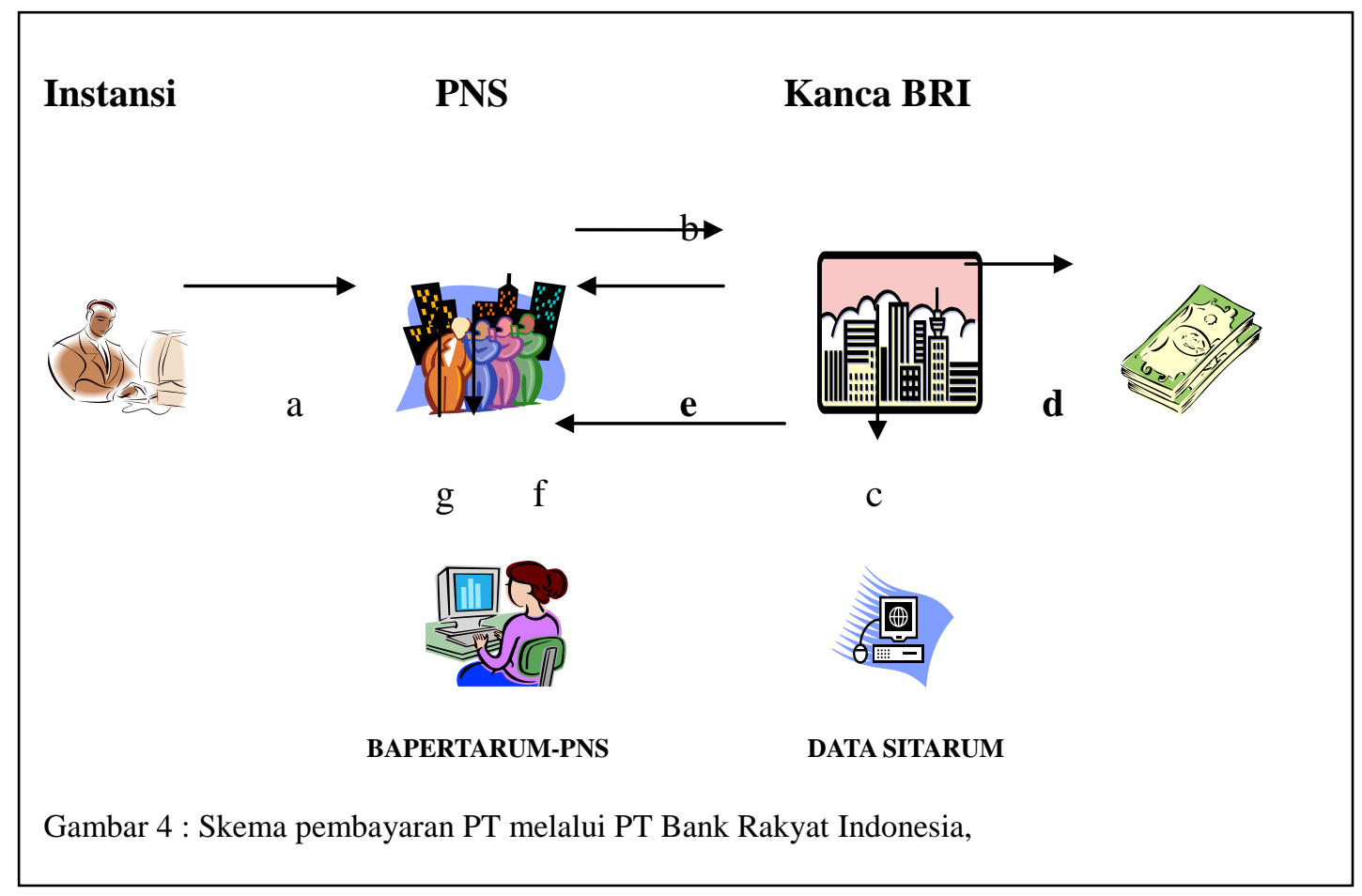




\section{J. Metodologi Penelitian}

\section{Tempat Penelitian}

Penelitian dilakukan di BAPERTARUM-PNS di Wisma Iskandarsyah Blok B2-B3, kaveling 12-14, Jalan Iskandarsyah Raya, Kebayoran Baru, Jakarta Selatan.

\section{Waktu Penelitian}
a. Tahap Persiapan
Tahap ini adalah tahapan awal yaitu melakukan tinjauan umun dan proses perijinan terhadap BAPERTARUM-PNS sebagai tempat penelitian.
b. Tahap pengumpulan data
Tahap ini adalah tahap pelaksanaan untuk memperoleh data penelitian melalui wawancara di BAPERTARUM-PNS.
c. Tahap pengolahan data.
Tahap ini untuk mengolah dan menganalisis data yang telah diperoleh dari hasil wawancara.
d. Tahap penyusunan laporan
Tahap ini merupakan tahap pembuatan penelitian.

\section{Metode Penelitian}

Data dan informasi yang telah dikumpulkan dan dihasilkan dari penelitian ini diolah secara manual maupun dengan menggunakan komputer. Data yang telah dikumpulkan, disusun dan diolah kemudian dianalisis secara kualitatif dan diinterpretasikan secara deskriptif.

Tehnik analisa data yang digunakan dalam penelitian ini adalah :

a. Analisa Data Perbandingan Realisasi Penyaluran Dana PT dan Hasil Rekonsiliasi Kesalahan Bayar dari Tahun 2005 s/d 2010,

Adalah analisa terhadap data-data sekunder hasil Realisasi transaksi PT melalui PT Bank Rakyat indonesia dan hasil pemeriksaan dokumen realisasi PT yang telah diolah kembali.

b. Analisa Hasil Kuesioner dan Wawancara dengan Petugas PT Bank Rakyat Indonesia di beberapa cabang di Indonesia.

c. Analisa SWOT yang berguna untuk mengambil Kebijakan yang dianggap penting mengatasi permasalahan ini.

Dalam pencapaian tujuan dan sasaran bidang yang sudah ditetapkan sebelumnya maka perlu dilakukan identifikasi seluruh faktor kekuatan dan kelemahan sehingga keduanya dapat dijadikan sumber kekuatan organisasi sebagai kapasitas sumber daya yaitu dengan mengenali kekuatan yang dimiliki dan kelemahan yang mungkin ada dan harus dihindari. Untuk menyusun strategi dan rencana kerja guna menanggulangi permasalahan yang telah dirumuskan, perlu dilakukan identifikasi faktor-faktor kunci yang dapat menunjang atau menghambat keberhasilan, baik faktor internal maupun eksternal.

Analisis yang digunakan untuk mengidentifikasi faktor-faktor tersebut dilakukan dengan menggunakan salah satu dari Teknik Analisis Managemen (TAM) yaitu teknik analisis SWOT. Teknik analisis SWOT ini adalah cara menerapkan metode ilmiah dalam merinci dan menilai keadaan lingkungan secara konprehensif guna memperoleh informasi faktor kunci keberhasilan dalam mencapai tujuan dan sasaran 
sehingga menghasilkan strategi, program dan kegiatan yang tepat dan menjelaskan identifkasi faktor-faktor internal dan eksternal dari keadaan lingkungan pada pelaksanaan kegiatan untuk mencapai tujuan dan sasaran pada Penyaluran Dana Taperum-PNS.

Faktor-faktor yang mempengaruhi keberhasilan organisasi dibagi dalam 2 (dua) kelompok yaitu faktor Internal dan eksternal yang dapat dijelaskan sebagai berikut :

1. Faktor Internal:

a) Strengths (kekuatan), adalah kemampuan melaksanakan atau menyelesaikan tugas dengan baik dan benar dengan sumber daya yang cukup dan dalam kondisi baik.

b) Weaknesses (kelemahan), adalah kemampuan yang rendah dalam menyelesaikan tugas dengan sumber daya yang terbatas dan kapasitas yang berkurang.

2. Faktor Eksternal

a) Opportunities (peluang) adalah Input yang dapat diolah dan mendatangkan suatu keuntungan atau manfaat yang besar dikemudian hari.

b) Threats (ancaman), adalah suatu kondisi yang dapat menghalangi, bahkan dapat menimbulkan resiko kegagalan dalam mencapai sesuatu yang diharapkan.

Adapun langkah-langkah pelaksanaan analsis SWOT dapat dibagikan dalam lima langkah:

1. Menyiapkan sesi SWOT.

2. Mengidentifikasi kekuatan dan kelemahan.

3. Mengidentifikasi kesempatan dan ancaman.

4. Melakukan ranking terhadap kekuatan dan kelemahan.

5. Menganalisis kekuatan dan kelemahan.

Hubungan ke 3 analisa tersebut diatas sangat erat dan dapat dijelaskan sebagai berikut :

a. Hasil data pemeriksaan berkas pencairan dana PT dikompilasikan dengan hasil analisa kuesioner dan wawancara dilapangan.

b. Setelah dilakukan Analisa terhadap faktor-faktor yang berpengaruh dengan Kesalahan Bayar dan analisa SWOT, seluruh hasil analisa tersebut dikumpulkan dan diolah.

c. Dan terakhir digunakan untuk kebijakan Pengambilan keputusan terhadap permasalahan Kesalahan Bayar tersebut.

Untuk lebih jelasnya dapat digambarkan dalam flowchart dibawah ini : 
Gambar 5 : Flowchart Bagan Tehnik Analisa Data
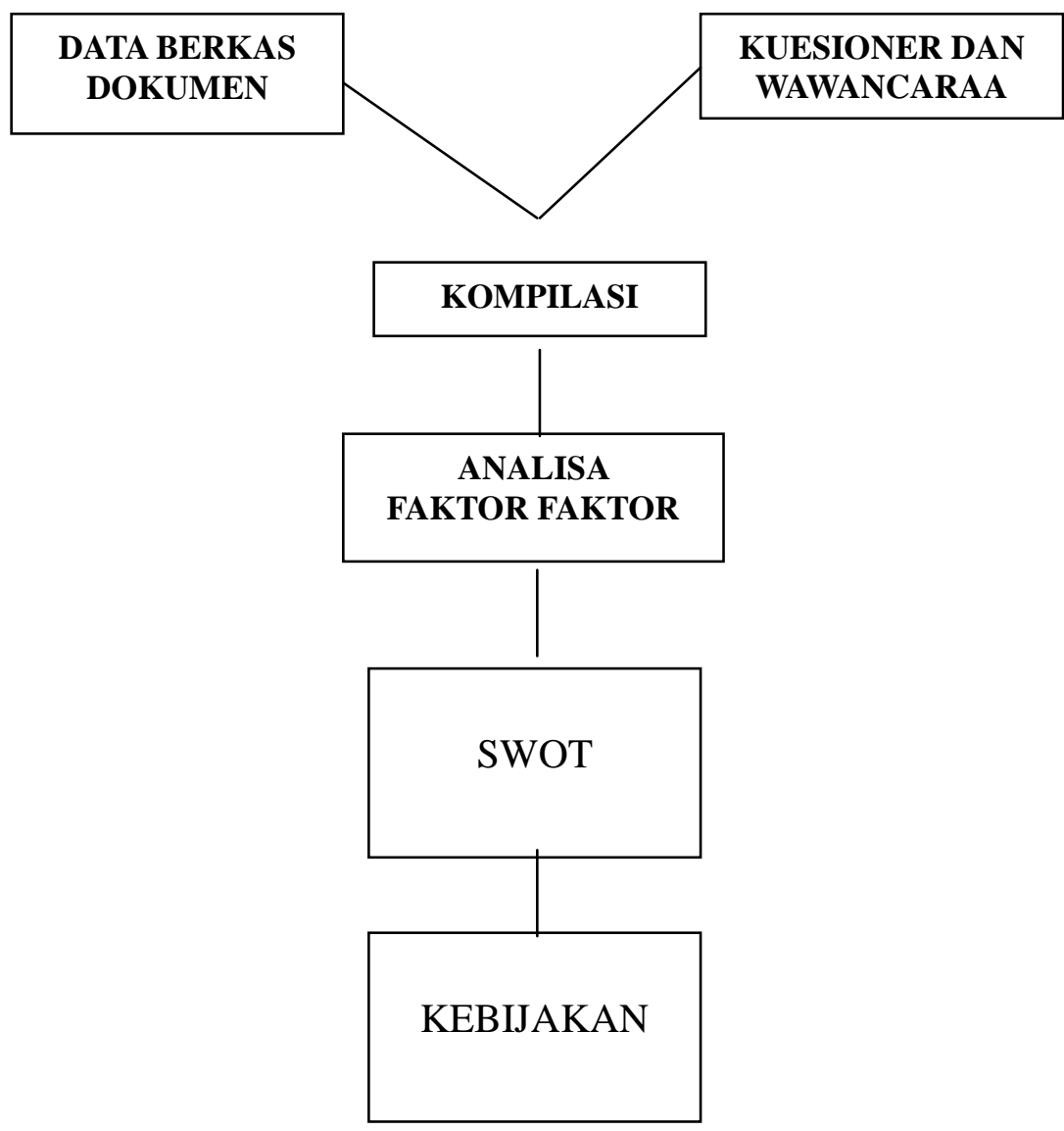

\section{K. Hasil Penelitian dan Pembahasan}

Dari hasil analisa SWOT dapat dijelaskan sebagai berikut :

Tabel 1 : Identifikasi Faktor Internal dan Eksternal

\begin{tabular}{|c|c|}
\hline \multicolumn{2}{|c|}{ FAKTOR INTERNAL } \\
\hline Kekuatan (Strengths=S) & Kelemahan (Weakness=W) \\
\hline $\begin{array}{l}\text { 1. PT Bank BRI sebagai Bank } \\
\text { Pemerintah terkemuka yang memiliki } \\
\text { banyak cabang di seluruh Indonesia } \\
\text { dan melaksanakan praktek "Good } \\
\text { Corporate Governance". } \\
\text { 2. PT Bank Rakyat Indonesia sebagai } \\
\text { salah satu Bank Pemerintah yang } \\
\text { memiliki pengalaman yang luas dalam } \\
\text { memberikan pelayanan kepada usaha } \\
\text { mikro, kecil dan menengah untuk } \\
\text { menunjang ekonomi masyarakat. }\end{array}$ & $\begin{array}{l}\text { 1. Human Error (SDM) } \\
\text { 2. Tenaga pelaksana di Front Office } \\
\text { adalah tenaga outsource, sehingga } \\
\text { kurang memiliki rasa kebanggaan } \\
\text { yang besar sebagai karyawan di PT } \\
\text { BRI. } \\
\text { 3. Tidak adanya Sangsi yang tegas } \\
\text { dalam memberikan Punishment } \\
\text { terhadap timbulnya Kesalahan Bayar } \\
\text { kepada Tenaga Outsource di cabang } \\
\text { dan tindak lanjut penyelesaian }\end{array}$ \\
\hline
\end{tabular}


3. Sebagai salah satu Bank Pemerintah terbesar PT Bank Rakyat Indonesia memiliki hubungan yang baik dan luas dengan para pejabat di tingkat Pemerintah Pusat \& Daerah. permasalahan tersebut oleh PT BRI.

\section{FAKTOR EKSTERNAL}

\section{Peluang (Opportunities $=0$ )}

1. Jumlah PNS yang banyak dan tersebar di Indonesia.

2. Kebijakan Pemerintah untuk menunjuk dan menetapkan pembayaran gaji PNS dan pensiun melalui PT Bank Rakyat Indonesia. dapat menjadikan PT Bank Rakyat Indonesia sebagai Bank Persepsi untuk seluruh pelayanan bagi PNS.

3. Kebijakan untuk peningkatan Kenaikan luran Tabungan Perumahan-PNS dari pemerintah sebagai "Potential Funding" bagi perbankan dalam menjalin kerjasama dengan BAPERTARUM-PNS.

\section{Ancaman (Threats $=\mathrm{T}$ )}

1. Pesaing dari Perbankan lain.

2. Tuntutan PNS atas pelayanan yang lebih baik dan akurasi pembayaran PT.

3. Hasil Evaluasi dan usulan dari Pemerintah untuk mengganti perbankan lain sebagai Bank Pelaksana.

\section{A. Memilih dan Menetapkan Faktor Kunci Keberhasilan}

1. Komparasi Urgensi Faktor Internal dan Eksternal

Untuk menentukan faktor yang menjadi kebutuhan pencapaian tujuan dan sasaran maka perlu dilakukan pengkondisian faktor-faktor tersebut terhadap setiap faktor yang teridentifikasi. Suatu faktor dikatakan penting terhadap tujuan dan sasaran yang diinginkan bila mempunyai nilai yang lebih tinggi dari faktor lain. Sejauhmana pentingnya faktor yang teridentifikasi secara internal dan eksternal, dapat dilakukan dengan melakukan komparasi antar faktor. Hasil komparasi antar faktor internal ini dapat dilihat pada matriks urgensi faktor internal pada tabel dibawah ini.

\section{Komparasi Urgensi Faktor Internal dan Eksternal}

Untuk menentukan faktor yang menjadi kebutuhan pencapaian tujuan dan sasaran maka perlu dilakukan pengkondisian faktor-faktor tersebut terhadap setiap faktor yang teridentifikasi. Suatu faktor dikatakan penting terhadap tujuan dan sasaran yang diinginkan bila mempunyai nilai yang lebih tinggi dari faktor lain. Sejauhmana pentingnya faktor yang teridentifikasi secara internal dan eksternal, dapat dilakukan dengan melakukan komparasi antar faktor. Hasil komparasi antar faktor internal ini dapat dilihat pada matriks urgensi faktor internal pada tabel dibawah ini.

\section{Keterangan :}

Bobot Faktor $(\mathrm{BF} \%)=\left(\mathrm{NF} / \sum \mathrm{NF}\right) \times 100 \%$

Makna Nilai Faktor ( NF ): 


\begin{tabular}{|l|c|}
\hline \multicolumn{1}{|c|}{ Nilai Faktor (NF) } & Bobot Faktor (BF \%) \\
\hline 5 = sangat besar / tinggi & 33.33 \\
\hline 4 = besar / tinggi & 26.67 \\
\hline 3 = sedang / cukup & 20.00 \\
\hline 2 = rendah / kecil & 13.33 \\
\hline 1 sangat rendah / kecil & 6.67 \\
\hline
\end{tabular}

Masing-masing faktor dibandingkan dengan faktor lainnya mana yang lebih urgen/penting, sehingga masing-masing akan memiliki Nilai Faktor (NF) dengan nilai antara 1- 5 (skala linkert).

Seperti halnya faktor internal, terhadap faktor eksternal juga dilakukan proses komparasi semua faktor eksternal yang ada. Hasil komparasi ini dapat dilihat pada matriks urgensi faktor eksternal pada table dibawah ini.

Tabel : Matriks Urgensi Faktor Internal

\begin{tabular}{|c|c|c|c|c|c|c|c|c|c|}
\hline No. & Faktor Internal & S1 & S2 & S3 & W1 & W2 & W3 & NF & BF\% \\
\hline S1 & $\begin{array}{l}\text { PT Bank BRI sebagai } \\
\text { Bank Pemerintah } \\
\text { terkemuka yang memiliki } \\
\text { banyak cabang di } \\
\text { seluruh Indonesia dan } \\
\text { melaksanakan praktek } \\
\text { "Good Corporate } \\
\text { Governance". }\end{array}$ & & S1 & S1 & W1 & S1 & S1 & 4 & 26,67 \\
\hline S2 & $\begin{array}{lr}\text { PT Bank } & \text { Rakyat } \\
\text { Indonesia sebagai salah } \\
\text { satu Bank } & \text { Pemerintah } \\
\text { yang } & \text { memiliki } \\
\text { pengalaman } & \text { yang luas } \\
\text { dalam } & \text { memberikan } \\
\text { pelayanan } & \text { kepada } \\
\text { usaha mikro, } & \text { kecil dan } \\
\text { menengah } & \text { untuk } \\
\text { menunjang } & \text { ekonomi } \\
\text { masyarakat } & \end{array}$ & & S1 & S2 & W1 & S2 & S2 & 3 & 20.00 \\
\hline S3 & $\begin{array}{l}\text { PT Bank } \\
\text { Indonesia mat } \\
\text { hubungan yang baik dan } \\
\text { luas dengan para } \\
\text { pejabat di tingkat } \\
\text { Pemerintah Pusat \& } \\
\text { Daerah. }\end{array}$ & S1 & & S2 & W1 & S3 & S3 & 2 & 13,33 \\
\hline W1 & Human Error (SDM) & W1 & W1 & W1 & & W1 & W3 & 4 & 26,67 \\
\hline W2 & $\begin{array}{l}\text { Tenaga pelaksana di } \\
\text { Front Office adalah }\end{array}$ & S1 & S2 & S3 & W1 & & W2 & 1 & 6,67 \\
\hline
\end{tabular}




\begin{tabular}{|c|c|c|c|c|c|c|c|c|}
\hline & $\begin{array}{lr}\text { tenaga } & \text { outsource, } \\
\text { sehingga } & \text { kurang } \\
\text { memiliki rasa } & \text { rebanggaan yang besar } \\
\text { sebagai karyawan di PT } \\
\text { BRI. }\end{array}$ & & & & & & & \\
\hline W3 & 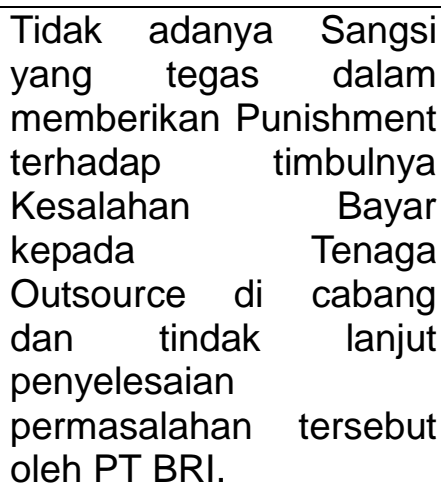 & S1 & S2 & S3 & W1 & W3 & 1 & 6,67 \\
\hline \multicolumn{2}{|r|}{ Jumlah } & & & & & & 15 & 100 \\
\hline
\end{tabular}

Tabel 9 : Matriks Urgensi Faktor Eksternal

\begin{tabular}{|c|c|c|c|c|c|c|c|c|c|}
\hline No & Faktor Eksternal & 01 & $\mathbf{O 2}$ & O3 & T1 & T2 & T3 & NF & BF\% \\
\hline 01 & $\begin{array}{l}\text { Jumlah PNS yang } \\
\text { tersebar di Indonesia }\end{array}$ & & O1 & O1 & 01 & T2 & T3 & 3 & 20,00 \\
\hline $\mathrm{O2}$ & $\begin{array}{l}\text { Kebijakan Pemerintah } \\
\text { untuk menunjuk dan } \\
\text { menetapkan } \\
\text { pembayaran gaji PNS } \\
\text { dan pensiun melalui PT } \\
\text { Bank Rakyat Indonesia. }\end{array}$ & 01 & & $\mathrm{O} 2$ & $\mathrm{O} 2$ & T2 & T3 & 2 & 13,33 \\
\hline O3 & $\begin{array}{lr}\text { Kebijakan } & \text { untuk } \\
\text { peningkatan } & \text { Kenaikan } \\
\text { luran } & \text { Tabungan } \\
\text { Perumahan-PNS dari } \\
\text { pemerintah, }\end{array}$ & O1 & 02 & & T1 & T2 & $\mathrm{O} 3$ & 1 & 6,67 \\
\hline T1 & $\begin{array}{l}\text { Pesaing dari Perbankan } \\
\text { lain. }\end{array}$ & O1 & $\mathrm{O} 2$ & T1 & & T1 & T1 & 3 & 20,00 \\
\hline T2 & $\begin{array}{l}\text { Tuntutan PNS atas } \\
\text { pelayanan yang lebih } \\
\text { baik dan akurasi } \\
\text { pembayaran PT. }\end{array}$ & T2 & $\mathrm{T} 2$ & T2 & T1 & & $\mathrm{T} 2$ & 4 & 26,67 \\
\hline T3 & $\begin{array}{lrr}\text { Hasil } & \text { Evaluasi } & \text { dan } \\
\text { usulan } & \text { dari } & \text { Pemerintah } \\
\text { untuk } & \text { mengganti }\end{array}$ & T3 & T3 & O3 & T1 & T2 & & 3 & 20.00 \\
\hline
\end{tabular}




\begin{tabular}{|c|l|l|l|l|l|l|c|}
\hline $\begin{array}{l}\text { perbankan lain sebagai } \\
\text { Bank Pelaksana. }\end{array}$ & & & & & & & \\
\hline Jumlah & & & & \\
\hline
\end{tabular}

Keterangan :

Bobot Faktor ( BF \% ) $=\left(\right.$ NF / $\sum$ NF $) \times 100 \%$ Makna Nilai Faktor ( NF ):

\begin{tabular}{|l|c|}
\hline \multicolumn{1}{|c|}{ Nilai Faktor (NF) } & Bobot Faktor (BF \%) \\
\hline 5 = sangat besar / tinggi & 33.33 \\
\hline 4 = besar / tinggi & 26.67 \\
\hline 3 = sedang / cukup & 20.00 \\
\hline 2 = rendah / kecil & 13.33 \\
\hline 1 sangat rendah / kecil & 6.67 \\
\hline
\end{tabular}

\section{Evaluasi Faktor Internal dan Eksternal}

Setelah nilai aspek urgensi yaitu Nilai Faktor (NF) dan Bobot Faktor (BF\%) bagi masing-masing faktor diperoleh, maka selanjutnya dilakukan evaluasi faktor internal dan eksternal agar dapat ditentukan besar nilai Faktor Kunci Keberhasilan (FKK). Nilai nilai Faktor Kunci Keberhasilan (FKK) ini diperoleh dengan mencari/menghitung nilai faktor dukungan yaitu Nilai Dukungan (ND) dan Nilai Bobot Dukungan (NBD) juga nilai keterkaitan yang mancakup Nilai Keterkaitan (NK, Nilai Rata-rata Keterkaitan (NRK) dan Nilai Bobot Keterkaitan (NBK) dan akhirnya diperoleh Total Nilai Bobot (TNB). Nilai TNB terbesar pada masing-masing faktor baik Internal maupun Eksternal ini merupakan Nilai Faktor Kunci Keberhasilan.

Penjelasan Nilai-nilai ini adalah sebagai berikut:

a. Nilai Dukungan (ND) ditentukan secara rasional (1-5).

b. Nilai Bobot Dukungan (NBD) $=(\mathrm{ND}) \mathrm{X}(\mathrm{BF}) \%$

c. Nilai Keterkaitan (NK) = Bobot keterkaitan satu faktor dengan faktor lainnya, ditentukan secara rasional $(0-5)$.

d. Nilai Rata-rata Keterkaitan $(N R K)=(T N K) /(\Sigma N-1) T N K=$ Total Nilai Keterkaitan $\mathrm{N}=$ Jumlah faktor internal dan eksternal yang dinilai.

e. Nilai Bobot Keterkaitan $(\mathrm{NBK})=(\mathrm{NRK} X \mathrm{BF} \%$.)

f. Total Nilai Bobot $(\mathrm{TNB})=(\mathrm{NBD}+\mathrm{NBK})$

Hasil evaluasi faktor internal dan eksternal untuk mencapai tujuan dan sasaran yang diinginkan dapat dilihat pada Tabel 10. Dalam penentuan nilai dukungan antara masingmasing faktor baik internal maupun eksternal dalam pencapaian tujuan dan sasaran, dilakukan dengan pendekatan penilaian skala 1-5. Sedangkan penentuan nilai keterkaitan menggunakan pendekatan nilai dengan skala 0-5. Arti dari masing-masing nilai tersebut adalah:

1) Angka 5 - sangat tinggi nilai dukungan/nilai keterkaitan

2) Angka 4 - Tinggi nilai dukungan/nilai keterkaitan

3) Angka 3 - Cukup tinggi nilai dukungan/nilai keterkaitan

4) Angka 2 - Rendah nilai dukungan/nilai keterkaitan

5) Angka 1 - Sangat rendah nilai dukungan/nilai keterkaitan

6) Angka 0 - Tidak mempunyai keterkaitan sama sekali. 


\section{Peta Posisi Kekuatan Organisasi}

Berdasarkan hasil evaluasi faktor Internal dan Eksternal dengan melihat semua nilai keterkaitan seperti yang dijelaskan pada tabel 10 diatas, maka dapat diambil kesimpulan bahwa Total Nilai Bobot (TNB) untuk masing-masing faktor adalah sebagai berikut:

- Faktor Kekuatan (Strength) $=4,6$

- Faktor Kelemahan (Weakness) $=2,9$

- Faktor Peluang (Opportunities) $=2,8$

- Faktor Ancaman (Threat)

$$
=4,0
$$

Berdasarkan hasil TNB dari masing-masing faktor tersebut, maka dapat dibuat Peta Posisi Kekuatan seperti yang diperlihatkan pada gambar 7 Perhitungan untuk mendapatkan koordinat yang dilakukan adalah sebagai berikut:

- Sumbu SW $=\sum$ TNB (S) $-\sum$ TNB $(W)=4,6-2,8=1,8$

- Sumbu OT $=\sum$ TNB (O) $-\sum$ TNB (T) $=2,8-4,0=-1,2$

Berdasarkan hasil tersebut, kemudian dibuat gambar atau diagram yang menggambarkan masing-masing kekuatan, kelemahan, peluang dan ancaman seperti ditunjukkan pada gambar dibawah ini.

Gambar : Grafik hasil Analisa SWOT

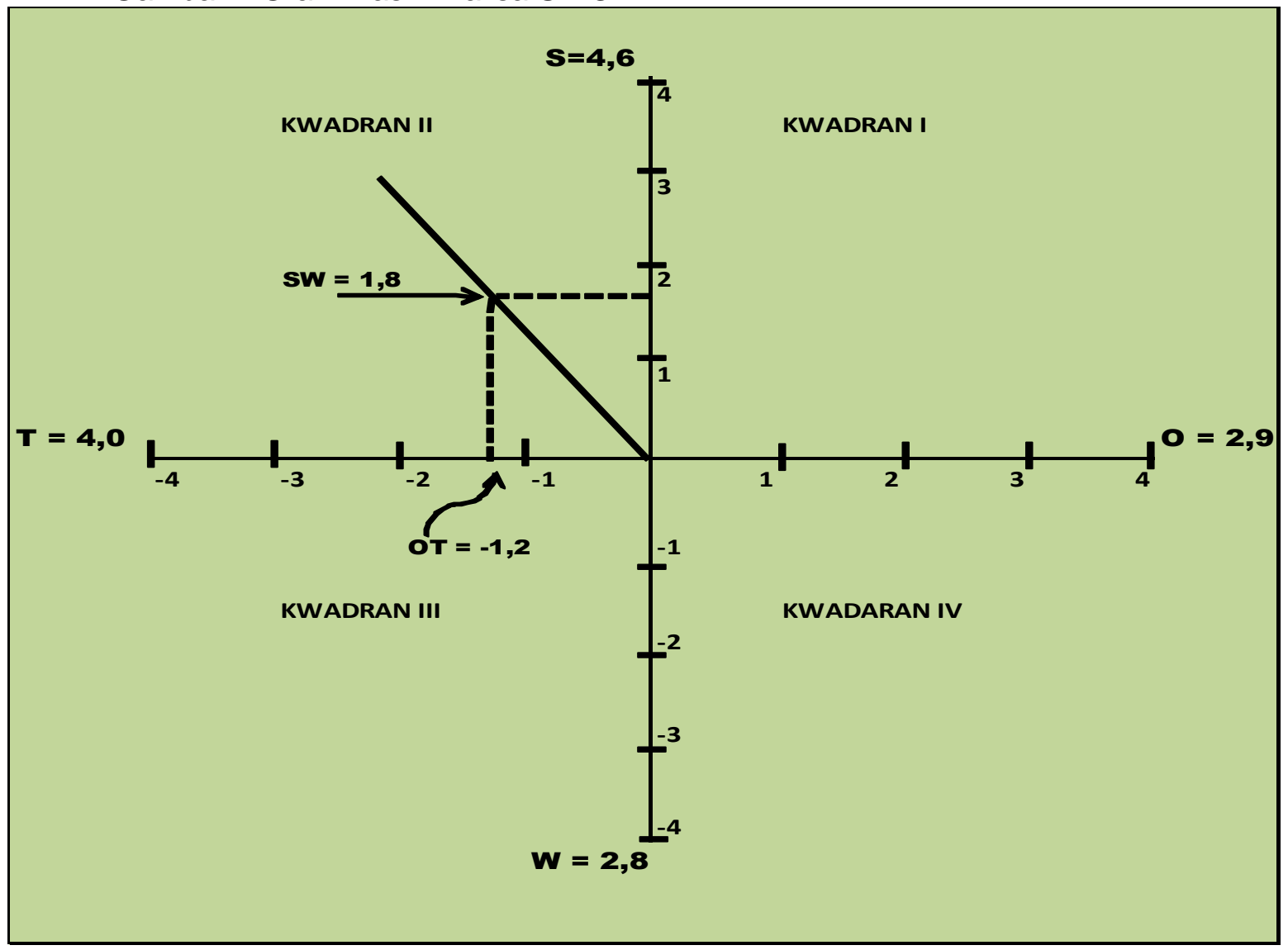

Berdasarkan hasil analisa SWOT yang telah dilakukan bahwa peta terdapat di Kuadran ke II, yang artinya ada 2 faktor yang sangat dominan, yaitu faktor Kekuatan dan faktor Ancaman, yang berarti bahwa Faktor Kekuatan yang cukup besar dalam mengatasi faktor Ancaman yang timbul dari luar. Sehingga disini citra PT Bank BRI 
sebagai Faktor Kekuatan utama, yang sudah terbangun sebagai Bank tertua di Indonesia yang memiliki pengalaman luas serta cabang yang cukup banyak dan tersebar di seluruh Indonesia harus dipertahankan dari Faktor Ancaman yang dalam hal ini merupakan Pesaing yang timbul dari pesaing perbankan sejenis yang dapat menjadi batu sandungan bagi PT Bank BRI.

Untuk mengimbangi Ancaman timbul khususnya dari pesaing perbankan lain tersebut, PT BRI harus menjaga dan meningkatkan reputasinya dimata nasabah dan mitra kerja yaitu dengan menerapkan beberapa langkah dan strategi yang dapat mendukung dan mengatasi ancaman yang timbul tersebut, yaitu dengan melakukan peningkatan pada bidang Pelayanan, pengembagan dalam "Bidang Sumber Daya Manusia melalui pelatihan-pelatihan, peningkatan Sistem Komputerisasi (IT) dan penyempurnaan Database PNS" yang selama ini menjadi masalah utama.

Saran yang dapat disampaikan terkait penelitian yang telah dilakukan bahwa

Pelaksanaan Perjanjian Kerjasama masih dapat dilanjutkan dengan beberapa perubahan, yaitu :

1. PT Bank Rakyat Indonesia

a. Agar PT BRI Pusat lebih meningkatkan Bimbingan Teknis secara kontinuitas dan berkesinambungan agar permasalahan di lapangan dapat lebih dini diketahui.

b. Percepatan terhadap Transfer Knowledge kepada petugas di lapangan dapat segera dilakukan dan diusulkan agar proses Rotasi Pegawai di cabang-cabang PT Bank Rakyat Indonesia khususnya petugas SDM yang menangani pelaksanaan pembayaran PT dapat lebih diminimalisasi agar program minimalisasi tingkat kesalahan menuju "Zero Percent" dapat tercapai dan citra PT Bank Rakyat Indonesia di mata PNS dan BAPERTARUM-PNS dapat semakin terpercaya.

c. Agar sistim Pelaporan Realisasi Penyaluran Dana PT dari PT Bank Rakyat Indonesia dapat lebih ditingkatkan sebagai upaya penyampaian pertanggungjawaban laporan Keuangan kepada BAPERTARUM-PNS.

\section{BAPERTARUM-PNS}

Langkah-langkah yang harus dilakukan BAPERTARUM-PNS adalah :

a. Meningkatkan kerjasama dengan Badan Kepegawaian Nasional dalam rangka penyempurnaan Database Riwayat Kepangkatan PNS di BAPERTARUM-PNS.

b. Membuat Surat Edaran Bersama ke seluruh Badan Kepegawaian Daerah di Indonesia untuk mengirimkan data Riwayat Kepangkatan PNS yang akan memasuki masa pensiun maksimal 6 bulan sebelum PNS yang bersangkutan pensiun.

c. Melakukan penginputan data riwayat Kepangkatan PNS dalam rangka penyempurnaan Data Riwayat Kepangkatan ke data base BAPERTARUM-PNS agar dapat dilakukan perhitungan pengembalian tabungan melalui pengembangan sistem komputer.

d. Melakukan perubahan mekanisme pembayaran PT, dimana seluruh penginputan data Riwayat Kepangkatan PNS dilakukan di BAPERTARUM-PNS sehingga petugas PT Bank Rakyat Indonesia hanya melakukan penginputan Nomor Induk Pegawai dan SK Pensiun PNS yang bersangkutan dan secara otomatis Jumlah Pengembalian Tabungan langsung terinformasi dari Sistem Komputerisasi tanpa harus menginput lagi Riwayat Kepangkatan PNS.

e. Dengan perubahan mekanisme tersebut diatas, diharapkan Kesalahan Bayar menjadi "Zero Persen", karena penginputan data dilakukan oleh BAPERTARUM-PNS melalui Sistem Komputerisasi. 


\section{L.Kesimpulan}

Berdasarkan hasil analisa SWOT yang telah dilakukan bahwa peta terdapat di Kuadran ke II, yang artinya ada 2 faktor yang sangat dominan, yaitu faktor Kekuatan dan faktor Ancaman, yang berarti bahwa Faktor Kekuatan yang cukup besar dalam mengatasi faktor Ancaman yang timbul dari luar.

\section{Daftar Pustaka}

Artle, Roland and Pravin Varaiya (1978). Life Cycle Consumption and Homeownership, Journal of Economic Theory, 18, 1, 38-58.

Denzin, Norman K. \& Tvona S. Lincoln (Eds.). Handbook of Qualitative ResearchTerjemahan oleh Dariyatno dkk. Yogyakarta: Pustaka Pelajar, 2003, hal. 350.

Keputusan Presiden No.14 Tahun 1993 tentang Tabungan Perumahan Pegawai Negeri Sipil.

Keputusan Presiden No.46 Tahun 1994 tentang Perubahan Atas Keputusan Presiden No.14 Tahun 1993 tentang Tabungan Perumahan Pegawai Negeri Sipil.

Keputusan Kepala Pelaksana Sekretariat Tetap BAPERTARUM-PNS Nomor: 90/KPTS/TAPERUM-PNS/VI/2000 tentang Petunjuk Teknis Penyaluran Bantuan BAPERTARUM-PNS.

Moeleong, Lexy J., 1998, Metodologi Penenlitian Kualitatif, Bandung: P.T. Remaja

Rosdakarya.

Patton, M. Q.(1990). Qualitative Evaluation and Research Methods ( $2^{\text {nd }}$ Ed). London: Sage Publication Ltd.

Peraturan Menteri Negara Perumahan Rakyat No.03/PERMEN/M/2009 tanggal 31 Agustus 1999 tentang Pemberhentian Layanan Bantuan kepada Golongan IVa \& IVb serta Pemberhentian Pemberian Jasa Tabungan Perumahan Pegawai Negeri Sipil.

Perjanjian Kerjasama antara BAPERTARUM-PNS dengan PT Bank Rakyat Indonesia No. 20/Add.PKS/TAPERUM-PNS/9/2008 \& B.547-DIR/HBL/09/08 tanggal 1 September 2008 tentang Pengembalian Tabungan Perumahan Pegawai Negeri Sipil.

Raco, J. R. 2010. Metode Penelitian Kualitatif. Jakarta: Grasindo, 2010

Sugiyono. (2005), Statistika untuk Penelitian. Bandung : Alfabeta. 